\title{
The Importance of Organizational Citizenship Behavior as a Mediator between Transformational Leadership and Managerial Performance
}

\author{
Hendrawan Suko Rahardjo ${ }^{1}$, Achmad Firdiansjah ${ }^{2}$, Mokhamad Natsir ${ }^{3}$. \\ ${ }^{1}$ Master Degree Program in Management, University of Merdeka Malang, Indonesia \\ ${ }^{2}$ Faculty of Economics and Business, University of Merdeka Malang, Indonesia \\ ${ }^{3}$ Faculty of Economics and Business, University of Merdeka Malang, Indonesia
}

\begin{abstract}
The study results on the effect of transformational leadership on employee performance show inconsistent results. It is necessary to re-examine and add a mediating variable, namely Organizational Citizenship Behavior (OCB), OCB as a mediating variable between transformational leadership and managerial performance. This article aims to analyze transformational leadership's effect on managerial performance through OCB at State Electricity Enterprise Ltd. This study's population were all Structural State Electricity Enterprise Ltd employees, which amounted to 48 people. Data analysis techniques using path analysis will present the path coefficient obtained from regression analysis in stages. The results of the study found that transformational leadership has a significant effect on managerial performance through $O C B$. OCB can mediate transformational leadership on managerial performance, which means that transformational leadership reflect by Intellectual Stimulation. Respondents agree that managerial employees learn to discover new things and show new ways of solving work problems and recognizing aspects. The critical aspects of a complex problem will allow leadership to recruit and interview and select new employees.
\end{abstract}

Keywords: Organizational Citizenship Behavior, Transformational, Managerial Performance.

\section{INTRODUCTION}

Facing an era of change and intense competition, State Electricity Enterprise Ltd. (PT. PLN Persero) must have the courage to face changes and win the competition. Resources owned by a company such as capital, work methods and equipment cannot provide optimal results if human resources do not support optimum performance. The success of State Electricity Enterprise Ltd. In achieving its goals is dependent mainly on managerial performance. Thus it is only natural that a manager must improve employee performance. Managerial performance can explaine as a form of the existence of the manager (leader) in completing work as effectively as possible,

Manager of State Electricity Enterprise Ltd. will produce a good performance and accept and act on environmental stimuli both internally and externally. For a manager, adapting to the environment and customers cannot be formed and embedded in every manager. This is an important reason to research on how to improve manager performance at State Electricity Enterprise Ltd. This is because the evaluation of performance carried out by managers varies, depending on the culture developed by each organization.

The study results on the effect of transformational leadership on employee performance show inconsistent results or a research gap, so it is necessary to re-examine and add a mediating variable, namely OCB, as a mediating variable of transformational leadership on managerial performance.

The concept of OCB was first discussed in the organizational research literature in the early 1980s, [1] arguing that OCB is a preferred behaviour that is not part of an employee's formal work obligations but supports the functioning of the organization effectively. OCB is individual behaviour that is free, not directly or explicitly recognized in the reward system and in promoting the effective functioning of the organization. Alternatively, in other words, OCB is employee behaviour that exceeds the mandatory role, which is not directly or explicitly recognized by the formal reward system.

The amount of professional responsibility of a manager makes it possible for a behaviour to emerge that exceeds the job role. A manager's profession requires mastery of knowledge and other special skills such as good interpersonal and communication skills. The flexibility of a manager's working hours reinforces the reason for the need for OCB. [2], shows that 
organizations with good OCB employees will have better performance than other organizations. [8] concluded that OCB affects employee performance.

A leader's model influences a manager who has high OCB in carrying out leadership. A leader must feel what subordinates feel and understand subordinates' needs and desires that implement in daily attitudes and behaviour. Besides, leaders also have an essential role in conveying the mission, communicating and conducting persuasion with language and sentences understood by subordinates. One of the many leadership models is transformational leadership. Transformational leadership can inspire and motivate followers to achieve greater than initially planned and internal rewards [3]. [4], stated that transformational leadership brings the situation towards high performance in organizations that face the demands of renewal.

Based on the previous description, the researcher is interested in researching the Effect of Transformational Leadership on Employee Performance through OCB at State Electricity Enterprise Ltd. This article aims to analyze transformational leadership's effect on managerial performance through OCB at State Electricity Enterprise Ltd.

\section{LITERATURE REVIEW}

The success of an organization in achieving its goals depends mainly on the performance of the manager. Managerial performance can be measured after the management accounting information system can be implemented and applied in an organization. Managerial performance is achieved when the organization as a whole or the business units' managers can perform tasks well to achieve the goals and objectives that have been set.

[5] conducted research by indicating that employees who have helpful behaviour and a sportsmanship attitude will produce optimal work productivity both in quantity and quality. Podsakoff concluded that the impact of organizational membership behaviour in the company affects increasing productivity (co-workers, managers), saving resources, being an effective means of coordinating workgroup activities, increasing organizational performance, and adapting to environmental changes.

[6] conducted a study on the relationship between leadership, organizational commitment and OCB at Uruguayan Hospital. The results showed that transformational leadership relates to OCB mediated by organizational commitment, while transactional leadership behaviour can increase employee commitment continuity.

[7] conducted research on the influence of transformational leadership, transactional leadership, self-efficacy, self-esteem and romance of leadership on job satisfaction and employee performance. The analysis used is path analysis, and it is concluded that transformational leadership, transactional leadership, and self-efficacy affect job satisfaction, while Self-Esteem and Romance of Leadership are not significant. Self-efficacy and the Romance of Leadership affect employee performance, while transactional leadership, transactional leadership and self-esteem do not affect performance.

[8] examined transformational leadership, job characteristics, and organizational performance. The analysis technique used is factor analysis, where when testing transformational leadership and transactional leadership using the Multifactor Leadership Questionnaire. The results of the study found that there is a positive relationship between transformational leadership and organizational performance with a probability value. This means that transformational leadership always puts forward change in the organization so that leaders need encouragement and support and cooperation from members to make these changes, which will ultimately impact organizational performance.

[8] tested the effect of transformational leadership on job satisfaction and employee performance. The analysis used is the Structural Equation Model, and it is concluded that the transformational leadership style affects job satisfaction, but has no effect on employee performance. Job satisfaction affects employee performance.

[9], conducted research to determine the effect of leadership on organizational commitment and performance. The result shows the potential influence of leadership on organizational commitment, which impacts increasing performance.

[10], conducted research with transformational leadership variables, job satisfaction and performance. The results show that Transformational Leadership affects job satisfaction and performance. Besides, job satisfaction affects performance.

[11], researched with variables of organizational climate, work motivation, organization justice, OCB and performance. The results show that Organizational Citizenship Behavior can improve employee performance.

A leader influences a manager who has high OCB in carrying out leadership. One of the many leadership is transformational leadership. Transformational leadership can change subordinates' behaviour into someone who feels capable, highly motivated and strives to achieve high and quality work performance in the workplace. A leader can transform subordinates 
in four ways [12], namely: a. Charisma (Idealized Influence), b-inspirations (Inspirational Motivation), c. Intellectual Stimulation, d. Individualized Consideration. The results of research [6] state that transformational leadership affects OCB.

OCB is the behaviour of individuals who have the freedom to choose, which is indirectly or not explicitly associated with the reward system and contributes to organizational functions' effectiveness and efficiency. According to [13], OCB is built from five dimensions, each of which is unique, namely: a. Altruism, b. Civic virtue, c. Conscientiousness, d. Courtesy, e. Sportsmanship. The results of research [5], [14], and [11] state that OCB affects employee performance.

The performance of individual members of the organization in managerial activities includes planning, investigation, coordination, supervision, staffing, negotiation and representation. The performance in this study is the manager's perception of managerial activities, which consists of nine dimensions of activities, namely: planning, investigation, staff selection, coordination, direction, negotiation, representation, control and evaluation. The results of research [15], [8], [10] state that transformational leadership affects employee performance.

\section{RESEARCH METHODS}

\subsection{Population and Sampling Techniques}

This study's population were all Structural Surabaya UIP JBTB I. State Electricity Enterprise Ltd employees, which amounted to 48 people. If the research object is less than 200 , it is better to research all of them, so that the research is a population study [16].

\subsection{Data Analysis Techniques}

Data analysis techniques using path analysis will present the path coefficient obtained from regression analysis in stages. The steps for testing the path diagram model are as follows: Building a model based on a concept or theory relevant to the field of study; Perform validity and reliability testing; Using standardized coefficient values for all paths in the structural equation model that has been created; Calculating the classical assumption test when multiple linear regression analysis is performed. Simple regression analysis is not recommended; $m$ Determine the level of prediction of the structural equation model, using the formula:

\section{RESULT AND DISCUSSION}

Kepemimpinan transformasional berpengaruh signifikan terhadap kinerja manajerial melalui Organizational Citizenship Behavior. Pengujian hipotesis dilakukan dengan analisis jalur yang menggunakan regresi linear, kemudian dilakukan penyaringan berdasarkan uji statisitik. Uji statistic ini menggunakan koefisien beta standarized coefficient (b standar). Jika nilai b signifikan maka koefisien jalur signifikan. Hasil peran Organizational Citizenship Behavior antara Kepemimpinan Transformasional terhadap Kinerja Manajerial ditampilkan pada table berikut.

Table 1. Recapitulation of Path Analysis Results

\begin{tabular}{|c|c|c|c|c|}
\hline Variable & Direct influence & $\begin{array}{c}\text { A } \\
\text { value }\end{array}$ & Indirect influence & $\begin{array}{l}\text { Total } \\
\text { Effect }\end{array}$ \\
\hline $\begin{array}{l}\text { Transformational leadership (X1) } \rightarrow \\
\text { Managerial Performance (Y2) }\end{array}$ & 0,36 & 0,00 & - & - \\
\hline $\begin{array}{l}\text { Transformational leadership (X1) } \rightarrow \\
\text { Organizational Citizenship Behavior } \\
\text { (Y1) }\end{array}$ & 0,77 & 0,00 & - & - \\
\hline $\begin{array}{l}\text { Organizational Citizenship Behavior } \\
(\mathrm{Y} 1) \rightarrow \text { Managerial Performance } \\
\text { (Y2) }\end{array}$ & 0,71 & 0,00 & - & \\
\hline $\begin{array}{l}\text { Transformational leadership (X1) } \rightarrow \\
\text { Organizational Citizenship Behavior } \\
(Y 1) \rightarrow \text { Managerial Performance } \\
\text { (Y2) }\end{array}$ & 0,36 & - & $\begin{array}{l}0,77 \times 0,71 \\
\quad=0.54\end{array}$ & 0,90 \\
\hline
\end{tabular}

Source: Attachments processed, 2020 
Based on the table, the total effect of Transformational Leadership on Managerial Performance is 0.90, more significant than the direct effect of 0.36. This shows that Organizational Citizenship Behavior acts as a mediator in the Influence of Transformational Leadership on Managerial Performance because the total value is greater than the direct effect.

The effect of transformational leadership on managerial performance through OCB State Electricity Enterprise Ltd., based on the test results, OCB can mediate the effect of transformational leadership on managerial performance.

These results indicate transformational leadership which is reflected primarily by intellectual Stimulation, which means that respondents tend to agree that the managerial employees of State Electricity Enterprise Ltd., always learn to discover new things, show new ways of solving work problems and recognize critical aspects of Complicated problems will enable the leadership to recruit, interview and select new employees.

Besides, the role of OCB is significant in improving managerial performance at State Electricity Enterprise Ltd., especially Altruism, which is helping colleagues voluntarily, willing to help friends who have heavy workloads and helping friends if they need help, Civic virtue, which is willing to attend training voluntarily to improve the company's image, willing to provide full service, keep up with changes in company developments and maintain the company's reputation.

Moreover, Sportsmanship, namely: refraining from complaining, having the willingness to tolerate without complaining, making input when there are subordinates who disagree and giving influence when some subordinates have disagreements that need to be maintained and maintained by employees at the managerial level.

\section{CONCLUSION}

Transformational leadership has a significant effect on managerial performance through OCB State Electricity Enterprise Ltd.; it is meant to improve State Electricity Enterprise Ltd. others' managerial performance, willing to sacrifice for fellow workers and be cooperative.

\section{REFERENCES}

[1] Robbins, P. Stephen\& Mary, C. 2015. Management, 11th Edition. New York, Prentice-Hall.

[2] Robbins. S. P., \& Judge, T. A. 2013. Essentials of Organizational Behavior (9th ed.). Upper Saddle River, NJ: Pearson Prentice Hall.

[3] Mondiani, Tria. 2012. Pengaruh Kepemimpinan Transformasional dan Kompensasi Terhadap Kinerja Karyawan PT. PLN (Persero) UPJ Semarang. Jurnal Administrasi Bisnis, Vol I Nomor 1 September 2012.

[4] Luthans, F. 2015. Organizational Behavior, Eleventh Edition, Boston, McGraw Hil.,

[5] Podsakoff, M. Phillip., Mackenzie, B. Scott, Paine, B. Julie, \& Bachrach.G.Daniel. 2000. Organizational Citizenship Behavior: a Critical Review of Theoretical Empirical Literature and Suggestions for Future Research. Journal of Management, 26 (3): 513-563

[6] Logomarsino, M. Raul \&Pablo,C. 2003. Relationship Among Leadership, Organizational Commitment, and OCB in Uruguayan Health Institutions, IESE Research Papers D/494: 1-22

[7] Awamleh, R., \& Al-Dmour, H. 2004. The Impact Of Transformational Leadership On Job Satisfaction And Self-Perceived Performance Of Banking Employees: The Case Of Jordan. International Business \& Economics Research Journal, Vol. 3, No. 11, 29-42.

[8] Purvanova. R.K., Bono. J.E., and Dzieweczynski.J. 2006. Transformational Leadership, Job Characteristics, and Organizational Citizenship Performance. Human Performance, 19(1), 1-22

[9] Steffens, N.K., Fonseca, M.A., Ryan, M.K., Rink, F.A., Stoker, J.I., \& Pieterse, A.N. 2018.How Feedback about Leadership Potential Impacts Ambition, Organizational Commitment, and Performance. The Leadership Quarterly, 29(6), 637-647

[10]Chandrasekara, WS. 2019. The Effect of Transformational Leadership Style On Employees Job Satisfaction and Job Performance: A Case of Apparel Manufacturing Industry In Sri Lanka. International Journal of Economics, Commerce and Management. Vol. VII, Issue 7: 385-393

[11]Handik, Yupono B. 2019. Organizational Citizenship Behavior Can Improve Organizational Climate, Work Motivation, And Organizational Justice On Employee Performance. Management And Economics Journal (Mec-J). Vol. 3 (2) 
[12] Bass,M. Bernard \& Avolio, J. Bruce. 1994. Improving Organizational Effectiveness Through Transformational Leadership. Thousand Oaks: SAGE Publications, Inc.

[13] Organ, W. Dennis,\& M. Konovsky. 1989. Cognitive versus affective determinants of organizational citizenship behaviour. Journal of Applied Psychology,74: 157-164.

[14] Yusuf, R. Mardiana, Hamid, N, Eliyana, A, Bahri, S and Sudarisman, A. 2012. The Antecedents of Employee's Performance: Case Study of Nickel Mining's Company, Indonesia. Journal of Business and Management, Volume 2, Issue 2, PP 22-28

[15] Mahoney, T. A., T. H. Jerdee and S. J. Carroll. 1963. Development of Managerial Performance: A Research Approach, Cincinnati: South Western Publ. Co

[16] Arikunto, S. 2013. Prosedur Penelitian Suatu Pendekatan Praktek. Jakarta, PT. Rineka Cipta. 